that what goes on in the nervous system during imagination is rather like what goes on during actual experience with the corresponding environmental circumstances. Given some latitude in expression, it could be said that to image a series of events produces the same neural changes as would be produced by direct experience with the events themselves.

The balance of the argument is perhaps not difficult to anticipate. It would suggest that the organism has had an experience essentially equivalent to that of behaving overtly and, in the case which is of interest here, being reinforced. Learning has thus occurred, and the effect of that learning has been to link a new series of responses with the problem situation. As the animal is, in fact, still in that situation, the learned responses are cued, and they are carried out.

In this fashion, cognition might possibly give rise to behavior. It is worth noting that it would do so in a completely determinate way, in accordance with the ordinary principles of learning. The notion that there might be some sort of free decision, on the part of the organism, to "use" its cognitive experience would be, in this framework, completely inappropriate.

\section{REFERENCES}

Atkinson, R. C., \& Wickens, T. D. Human memory and the concept of reinforcement. In $R$. Glaser (Ed.), The nature of reinforcement. New York: Academic Press, 1971.

Berlyne, D. E. Structure and direction in thinking. New York: Wiley, 1965

Bindra, D. A unified account of classical conditioning and operant training. In A. H. Black and W. F. Prokasy (Eds.)
Classical conditioning II. New York: Appleton-Century-Crofts, 1972.

Bolles, R. C. Reinforcement, expectancy, and learning. Psychological Review, 1972, 79, 394-409.

Carroll, J. B. Reinforcement: Is it a basic principle, and will it serve in the analysis of verbal behavior? In R. Glaser (Ed.), The nature of reinforcement. New York: Academic Press, 1971.

Cofer, C. N., \& Appley, M. H. Motivation: Theory and research. New York: Wiley, 1964.

Estes, W. K. Reward in human learning: Theoretical issues and strategic choice points. In R. Glaser (Ed.), The nature of reinforcement. New York: Academic Press, 1971.

Hilgard, E. R., \& Bower, G. H. Theories of learning. (3rd ed.) New York: Appleton-Century-Crofts, 1966.

Homme, L. Perspectives in psychology: XXIV. Control of coverants, the operants of the mind. Psychological Record, $1965,15,501-511$.

Logan, F. A. Incentive theory, reinforcement, and education. In $\mathrm{R}$. Glaser (Ed.), The nature of reinforcement, New York: Academic Press, 1971.

McMahon, C. E. Images as motives and motivations: A historical perspective. American Journal of Psychology, 1973, 86,
465-490.

Mowrer, O. H. Learning theory and the symbolic processes. New York: Wiley, 1960.

Neisser, U. Changing conceptions of imagery. In P. W. Sheehan (Ed.), The function and nature of imagery. New York: Academic Press, 1972.

Skinner, B. F. Behaviorism at fifty. In T. W. Wann (Ed.) Behaviorism and phenomenology: Contrasting bases for modern psychology. Chicago: University of Chicago Press,
1964.

Smith, K. Conditioning as an artifact. Psychological Review, $1954,61,217-225$. Reprinted with note in $G$. Kimble (Ed.), Foundations of conditioning and learning. New York: Appleton-Centurv-Crofts, 1967.

Smith, K. Behavior and conscious experience: A conceptual analysis. Athens, Ohio: Ohio University Press, 1969.

Woodworth, R. S. Reinforcement of perception. American Journal of Psychology, 1947, 60, 119-124.

Zikmund, V. Physiological correlates of visual imagery. In P. W. Sheehan (Ed.), The function and nature of imagery. New York: Academic Press, 1972.

(Received for publication May 20, 1974.)

\title{
The effect of septal and amygdaloid lesions on the duration of emotionality in the white rat
}

\author{
MELVIN L. GOLDSTEIN* \\ Indiana University at Kokomo, Kokomo, Indiana 46901
}

\begin{abstract}
The duration of the septal syndrome and the reciprocal relationship of the septal and amygdaloid nuclei in their effect on emotional behavior were investigated. Gross lesions were placed in the septal nuclei and amygalaloid complex, minute lesions were placed in the medial and lateral septal nuclei, and the effects on emotional behavior were measured over a period of 12 days by means of a rating scale. The septal lesions increased emotionality, but the amygdaloid lesions did not decrease emotionality. The locus for the rage syndrome was found in the lateral septal nucleus.
\end{abstract}

*These experiments were conducted at the University of Wisconsin. Preparation of this report was supported, in part, by Grant No. 26-631-32 awarded by the Indiana University Office of Research and Advanced Studies. Charles Borneman, Jr., made the drawings; Rita Martin and Andy Elledge typed the manuscript. The writer wishes to express his appreciation to his wife, Daidee, for her patience and helpful comments.
Lesions of the septal nuclei in the rat produce a behavioral "rage" syndrome which is characterized by an exaggerated startle response, difficulty in handling, and exaggerated "attack" behavior (Brady \& Nauta, 1953, 1955). These effects have been replicated several times 


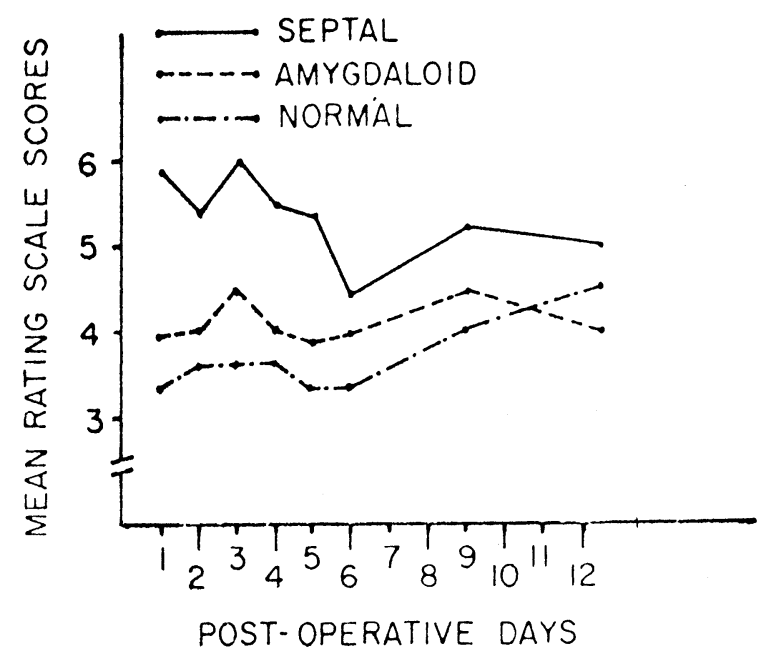

Fig. 1. Postoperative emotionality ratings for septal, amygdaloid, and normal rats.

(e.g., King, 1958; King \& Meyer, 1958; Yutzey, Meyer, \& Meyer, 1964; Krieckhaus, Simmons, Thomas, \& Kenyon, 1964).

The effects of septal lesions on emotional behavior, as measured by behavioral rating scales, last for 12 days when daily ratings of emotional behavior are made (Brady \& Nauta, 1953) and 60 days when ratings are made every 15 days. The facilitative effects of septal lesions on two-way active avoidance conditioning have been reported 5 and 10 day postoperatively, but not 2 days postoperatively (Miczek, Kelsey, \& Grossman, 1972). The facilitative effect apparently remains after the hyperemotionality has dissipated (Krieckhaus, Simmons, Thomas, \& Kenyon, 1964).

Ablation of the amygdaloid complex of the rat yields a "placid" preparation which is easy to handle. This "placidity" has not, however, been reflected in the behavioral rating scale measure (King \& Meyer, 1958). Amygdaloid lesions interfere with acquisition of active avoidance responses (Horvath, 1963; King, 1958; Robinson, 1963), and with the acquisition and retention of a conditioned fear response (Goldstein, 1965).

Because of these contrasting and opposite effects of septal and amygdaloid lesions on emotional conditioning, the two nuclei are sometimes thought to be reciprocally related in their effect on general emotionality (King, 1958; King \& Meyer, 1958). Ablation of the septal nuclei should, therefore, release explosive "rage" behavior, and ablation of the amygdaloid nuclei should result in a "placid" preparation. The septal area may, therefore, exert inhibitory influences on the amygdala and the amygdaloid nuclei may serve as an excitatory area (e.g., Zeman \& Innes, 1963).

The purpose of the present experiments was to describe the time course of the septal syndrome during the immediate postoperative period, as measured by a behavioral rating scale, and to identify the specific septal nuclei responsible for the effect.

\section{METHOD}

\section{Subjects}

The Ss were 18 naive male albino rats obtained from the Holtzman Company, Madison, Wisconsin. They were 120 days old and weighed $400-420 \mathrm{~g}$ at the start of the experiment. They were hou sed in individual cages during the experiments.

\section{Experimental Design}

There were six experimental groups. Group I sustained bilateral lesions of the septal nuclei $(\mathrm{N}=4)$; Group II sustained bilateral lesions of the amygdaloid complex $(\mathrm{N}=4)$; Group III was a normal unoperated control $(\mathrm{N}=3)$; Group IV sustained small bilateral lesions of the lateral septal nucleus $(\mathrm{N}=2)$; Group V sustained small bilateral lesions in the medial septal nucleus $(\mathrm{N}=2)$; and Group VI sustained unilateral lesions to the lateral septal nucleus $(\mathrm{N}=3)$.

The behavioral rating scale u sed by Brugge (1963) was used on Postoperative Days $1,2,3,4,5,6,9$, and 12. Animals were handled only during the rating sessions.

\section{Behavioral Rating Scale}

A three-category behavioral rating scale was used. The categories were: (A) response to stick placed in front of the animal' snout: (1) ignores, (2) nibbles stick, then ignores, (3) aggressively attacks stick; (B) response to a light tap on the back: (1) no response, (2) animal turns, moves away, (3) strong startle response, bounding around cage, vocalizing; (C) response to handling with a glove: (1) no struggling, (2) slight struggling, animal easily grasped, (3) biting, difficult to grasp.

\section{Surgical and Histological Procedures}

The lesions were produced electrolytically with the aid of a Baltimore rat stereotaxic instrument. The lesioning electrode was made from a No. 23 gauge "Yale" $1 \frac{1}{2}$-in. stainless steel hypodermic needle which was insulated, except at the tip, with Epoxylite.

The stereotaxic coordinates used for the septal lesions varied, depending upon the size of the lesion to be made, from $0 \mathrm{~mm}$ anterior to the bregma, $3.0 \mathrm{~mm}$ lateral to the midline, $5.5 \mathrm{~mm}$ below the dural tissue at the angle of 25 deg toward the midline, to $1.0 \mathrm{~mm}$ anterior to the bregma, $3.0 \mathrm{~mm}$ lateral to the midline, $5.5 \mathrm{~mm}$ below the dural tissue at an angle of $25 \mathrm{deg}$ toward the midline. The stereotaxic coordinates used for the amygdaloid lesions were $2.5 \mathrm{~mm}$ posterior to the bregma, $4.5 \mathrm{~mm}$ lateral to the midline, $8.0 \mathrm{~mm}$ below the dural tissue.

$\mathrm{S}$ was anesthetized with $0.3 \mathrm{cc}$ sodium pentobarbital and placed into the stereotaxic instrument; an incision was then made along the midline of the scalp. The skin and fascia were retracted with hemostats, and small burr holes were made in the skull at the appropriate coordinates. A $2.0-\mathrm{mA}$ anodal current, lasting for $20 \mathrm{sec}$, was used to produce the lesions for Group I. Variations in the location and size of the septal lesions were obtained by varying the coordinates, as described above, and by varying the current intensity from $0.5 \mathrm{~mA}$ for $10 \mathrm{sec}$ to $1.0 \mathrm{~mA}$ for $10 \mathrm{sec}$.

At the end of the experiment, frozen coronal sections, 40 micra thick, were made of the brain and were stained with cresyl violet. The sections were examined microscopically.

\section{RESULTS}

\section{Behavioral Findings}

The mean scores on the behavioral rating scale for Groups I, II, and III (septal, amygdaloid, normal) on Postoperative Days 1-12 are shown graphically in Fig. 1.

The septal emotionality effect diminished in severity by Postoperative Day 9 and dissipated entirely by 


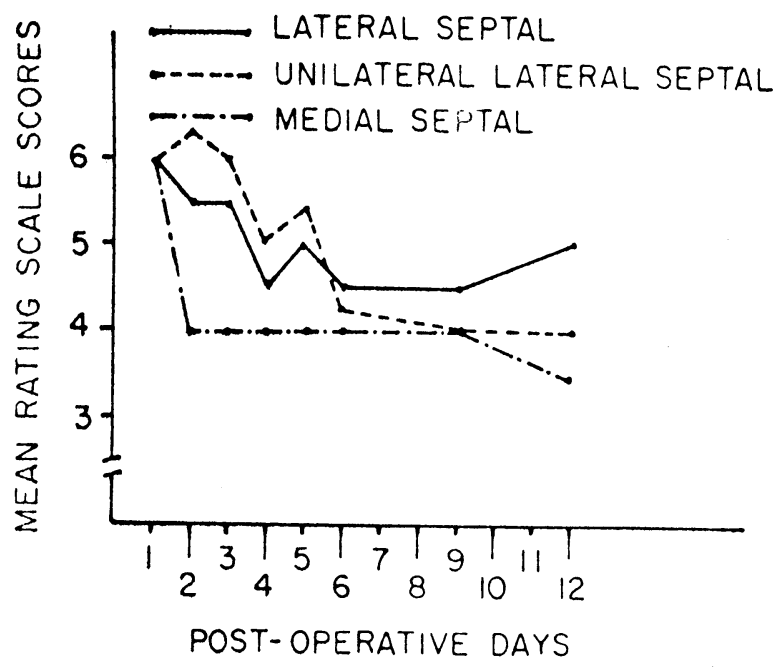

Fig. 2. Postoperative emotionality ratings for lateral septal, medial septal, and unilateral septal lesioned rats.

Day 12 . The septal lesioned animals showed a relatively high level of "emotionality" on the first 5 postoperative days, when compared with the normal animals. The overall differences in "emotionality" between the septal and normal animals on Days 1-12 were significant beyond the .01 level of confidence $(\mathrm{t}=7.73, \mathrm{df}=5)$. On Day 1, the difference in "emotionality" between the septal and normal animals was significant beyond the .01 level of confidence $(t=6.50, d f=5)$. By Day 12 , there were no significant differences between the two groups.

The overall difference in "emotionality" between the amygdaloid lesioned animals and the normals, on Postoperative Days 1-12, was significant only at the .05 level of confidence $(\mathrm{t}=2.70, \mathrm{df}=5)$.

Figure 2 shows the results for Group IV, Group V, and Group VI. Since the Ns for these groups were small, no statistical comparisons were made.

\section{Histological Findings}

Group $1-100 \%$ of the septal nuclei were destroyed, including the column of the fornix and the preoptic area. Group II-most of the amygdaloid complex was destroyed. Group IV-50\% of the lateral septal nucleus was destroyed and the medial septal nucleus was left intact. Group V-100\% of the medial septal nucleus was destroyed and the lateral septal nucleus was left intact. Group VI-50\% of the lateral septal nucleus was destroyed. The Konig \& Klippel (1963) atlas was used to identify all the lesions.

\section{DISCUSSION}

The major finding of this experiment was that the septal "emotionality" syndrome has a duration of less than 12 days in the white rat when ratings are made approximately daily. These results replicate the findings of Brady and Nauta (1953). ${ }^{1}$ Lesions to the amygdaloid complex raised the level of "emotionality" only slightly above normal, but not to the level observed for the septal lesioned animals.

The neural locus of the inhibitory mechanism, the release from which is presumably responsible for the septal emotionality syndrome, is probably in the lateral septal nucleus rather than the medial septal nucleus. Lesions of the medial septal nucleus had little effect on emotional behavior, as measured by the rating scale, while unilateral and bilateral lesions of the lateral septal nucleus increased the general level of emotionality. These findings corroborate the recent results of Clody and Carlton (1969), who have shown that medial septal lesions produce "hyperplacid" animals. The lateral septal nucleus is, therefore, most likely the area responsible for the rage syndrome.

The finding that the animals with lesions to the amygdaloid complex rated somewhat higher than normals, but not as high as septals, suggests that the lateral septal nuclei and the amygdaloid complex are not reciprocally related in their effect on emotionality as measured by the behavioral rating scale used in the present experiment. The functional relationship between the septal and amygdaloid nuclei in their effect on emotional behavior is probably not the simplistic reciprocal relationship which has been postulated, and is most likely modified by influences from other areas of the limbic system to which these areas send projections.

\section{REFERENCES}

Brady, J. V., \& Nauta, W. J. H. Subcortical mechanisms in emotional behavior: Affective changes following septal forebrain lesions in the albino rat. Journal of Comparative \& Physiological Psy chology, 1953, 46, 339-346.

Brady, J. V., \& Nauta, W. J. H. Subcortical mechanisms in emotional behavior: The duration of affective changes following septal and habenular lesions in the albino rat Journal of Comparative \& Phy siological Psychology, 1955, 48, 412-420.

Brugge, J. F. Electroencephalographic changes following septal lesions in the unrestrained rat. Unpublished doctoral dissertation, University of Illinois, 1963.

Clody, D. E., \& Carlton, P. L. Behavioral effects of lesions of the medial septum of rats. Journal of Comparative \& Physiological Psychology, 1969, 67, 344-351.

Goldstein, M. L. Effects of hippocampal, amygdala, hypothalamic, and parietal lesions on a classically conditioned fear response. Psy chological Reports, 1965, 16, 211-219.

Horvath, F. L. Effect of basolateral amydgalectomy on three types of avoidance behavior in cats. Journal of Comparative \& Physiological Psychology, 1963, 56, 380-389.

King, F. A. Effects of septal and amygdaloid lesions on emotional behavior and conditioned avoidance responses in the rat. Journal of Nervous \& Mental Diseases, 1958, 126, 57-63.

King, F. A., \& Meyer, P. M. Effects of amygdaloid lesions upon septal hyper-emotionality in the rat. Science, 1958, 128, 655-656.

Konig, J. R. R., \& Klippel, R. A. The rat brain: A stereotaxic atlas. Baltimore: Williams \& Wilkins, 1963.

Krieckhaus, E. E., Simmons, H. J., Thomas, G. J., \& Kenyon, J. Septal lesions enhance shock avoidance behavior in the rat. Experimental Neurology, 1964, 9, 107-113.

Miczek, K. A., Kelsey, J. E., \& Grossman, S. P. Time course of effects of septal lesions on avoidance, response suppression, and reactivity to shock. Journal of Comparative \& Physiological Psychology, 1972, 79, 318-327.

Robinson, E. Effect of amygdalectomy on fear-motivated behavior in rats. Journal of Comparative \& Physiological Psychology, 1963, 56, 814-820.

Yutzey, D. A., Meyer, P. M., \& Meyer, D. R. Emotionality changes following septal and neocortical ablations in rats. Journal of Comparative \& Phy siological Psychology, 1964, 58 . 463-465.

Zeman, W., \& Innes, J. R. M. Craigie's neuroanatomy of the rat. New York: Academic Press, 1963.

\section{NOTE}

1. Brady and Nauta (1953) used three independent judges as raters. The present experiment used only one rater, but obtained results similar to those of Brady and Nauta (1953).

(Received for publication April 26, 1974.) 